\title{
The Global Mobility Infrastructure: Reconceptualising the Externalisation of Migration Control
}

\author{
Thomas Spijkerboer \\ Professor of Migration Law, Vrije Universiteit Amsterdam, Raoul Wallenberg \\ visiting professor of Human Rights and Humanitarian Law, Lund University \\ t.p.spijkerboer@vu.nl
}

\begin{abstract}
Since the end of the Cold War, migration law and policy of the global North has been characterised by externalisation, privatisation and securitisation. These developments have been conceptualised as denying access to migrants and as politics of non-entrée. This article proposes to broaden the analysis, and to analyse unwanted migration as merely one form of international human mobility by relying on the concept of the global mobility infrastructure. The global mobility infrastructure consists of the physical structures, services and laws that enable some people to move across the globe with high speed, low risk, and at low cost. People who have no access to it travel slowly, with high risk and at high cost. Within the global mobility infrastructure, travellers benefit from advanced forms of international law. For the excluded, international law reflects and embodies their exclusion before, during and after their travel to the global North. Exclusion is based on nationality, race, class and gender. The notion of the global mobility infrastructure allows for questioning the way in which international law reproduces these forms of stratification.
\end{abstract}

\section{Keywords}

externalisation - human rights - migration control 
Since the end of the Cold War, the migration law of the global North has been characterised by externalisation, privatisation and securitisation. Examples are the Australian Pacific 'Solution', the reinforcement of the US-Mexico border and the European policies beefing up the capacity of states on the other side of their sea borders to prevent people from departing towards Europe. These developments have been conceptualised as denying access to migrants. ${ }^{1}$ An evocative term for the rationale underlying these developments is non-entrée. ${ }^{2}$ Typical of the framework in which these developments are understood is the opening sentence of an-excellent-recent article by Bosworth, Fili and Pickering: 'As states around the world have responded to growing numbers of people on the move by tightening their borders, (...). ${ }^{3}$

The main argument of this article is that the focus on denying access, nonentrée and the tightening of borders risks ignoring that migration is one form of (and generally: an unwanted form of) human mobility. Human mobility in general is considered as a very positive thing. It is boosted by national and international policies, and it is considered to be of great value both in itself and for its socio-economic significance. When cross-border movement is presented as desirable, the concept of mobility is used, while when it is considered problematic or potentially unwanted, the term migration is used. ${ }^{4}$ In that sense, migration is the annoying little sibling of mobility. In this article, I propose to analyse migration policy not in isolation from, but as part of the wider phenomenon of the regulation of mobility. The notion of non-entrée sheds light on particular aspects of reality while de-emphasising others. This article will sketch some new analytical and normative approaches that become possible once restrictive migration policies are seen as just one form of the regulation of human mobility.

* Work on this article has been funded through the project 'Border Policies and Sovereignty. Human rights and the right to life of irregular migrants', grant no. 453-12-004 of NWO (Netherlands Organisation for Scientific Research).

1 T. Gammeltoft-Hansen, Access to Asylum: International refugee law and the globalization of migration control (Cambridge: Cambridge University Press, 2011); M. den Heijer, Europe and Extraterritorial Asylum, (Oxford: Hart Publishing, 2011).

2 T. Gammeltoft-Hansen \& J.C. Hathaway, Non-refoulement in a world of cooperative deterrence, 53 Columbia Journal of Transnational Law 2015, p. 235-284.

3 M. Bosworth, A. Fili \& S. Pickering, Women and border policing at the edges of Europe, 44:13 Journal of Ethnic and Migration Studies 2017, p. 2182-2196, DOI:10.1080/1369183X.2017.1408459, emphasis added.

4 E.g. M. van Ostaijen, 'Between migration and mobility discourses: the performative potential of intra-European movement', 11 Critical Policy Studies 2017, p. 166-19o. 
This article proposes to use the concept of the global mobility infrastructure. It is not the aim of this article to give a comprehensive overview of relevant empirical or legal developments, but instead to refer to such developments only in order to clarify the proposed conceptual move. In addition, this article does not argue against using the notions of non-entrée and denial of access. Clearly, these notions refer to a process that is at work in the laws and policies of the global North. But an exclusive focus on non-entrée may obscure the wider process of stratification of which these laws and policies are part. The global North does not only exclude people; it also welcomes particular categories of people and stimulates their cross-border movement, even if they are headed for the North. Placing non-entrée in this wider context allows for analyses that cannot be made as long as one sticks to non-entrée as the dominant analytical tool. Therefore, this article does not merely propose another term, but proposes another object of study. It proposes to analyse the law and politics of non-entrée as part of a wider set of laws and policies regulating global human mobility. There are important aspects of non-entrée that come to light once the wider context I propose to call the global mobility infrastructure is taken into account.

\section{Increasing Mobility}

Denying access to migrants, non-entrée policies and the tightening of borders are by no means the only developments that occurred since the end of the Cold War. In the same period, access to countries of the global North has increased, and this was in conformity with the aims of policies of the global North. Exemplary is the number of passengers arriving annually at European airports from outside the EU. Between 2002 and 2017, their number increased from 181 million to 345 million. ${ }^{5}$ The number of passengers arriving from outside the EU increased at Frankfurt am Main Airport from 14.2 million in 1993 to 30 million in 2017, and at Amsterdam Schiphol airport from 76.00o to 27,6 million in the same period. ${ }^{6}$ This shows that the entry of people from all over the world has been facilitated in major ways. In that sense borders have become

5 These data concerns Belgium, the Czech Republic, Denmark, Germany, Estonia, Spain, France, Italy, Latvia, Luxembourg, Hungary, Malta, Netherlands, Austria, Portugal, Slovakia, Finland, Sweden and the United Kingdom, source Eurostat, International extra-EU air passenger transport by reporting country (avia_paexcc), (Luxembourg: Eurostat), https:// ec.europa.eu/eurostat/data/database, last accessed 21 October 2018.

6 Eurostat: International extra-EU air passenger transport by main airports (avia_paexac), (Luxembourg: Eurostat), https://ec.europa.eu/eurostat/data/database, last accessed 21 October 2018. 
more open instead of closed. A common trope holds that capital and goods can circulate, but not people; but these numbers show that people circulate too. Global mobility increases at an accelerating rate. The global number of air passengers has increased from 310 million in 1970 to 3.98 billion in $2017^{7}-$ almost 13 times as much. This includes domestic flights, and it includes people who get on a plane more than once a year. But nonetheless, the idea of increasing border closure represents only part of the picture. It represents a particular reality which cannot be denied, being the reality of people whose cross-border travel is considered unwanted by the global North. However, it does not reflect the reality that the cross-border travel of other people is highly desired and encouraged. It does merit our attention that borders are tightened for some, and relaxed for many others.

\section{The Global Mobility Infrastructure}

The expansion of human movement across borders over the past decades has been made possible by the construction of a global infrastructure that promotes human mobility. This global mobility structure has three closely related elements:

1. Physical structures: air and sea ports; airplanes and ferries; hotels, restaurants and other locations to cater to mobile people; roads and railroads to transport people to the major hubs that harbours and, in particular, airports have become;

2. Services: travel agencies, consular officials, visa intermediaries, hotel and catering personnel, people working in transport companies (airline and ferry companies, domestic transport to hubs);

3. Law: the liberalisation of international people transport, especially in aviation; the amendment of laws to allow for mergers of previously national transportation companies; change of visa regulations, partly tightening and partly liberalising control.

The expansion of human mobility that is being made possible by the global mobility infrastructure is highly desired. All elements of the infrastructure have been facilitated in major ways by national governments and international organisations such as the UN agency ICAO (the International Civil Aviation Organisation). A crucial element of the global mobility infrastructure is its accessibility. The crux is that people can travel from anywhere in the world to anywhere else in the world speedily, safely and cheaply. For that, it is essential

7 World Bank: Air transport, passengers carried (Washington: World Bank Group), https:// data.worldbank.org, last accessed 21 October 2018. 
that the global mobility infrastructure can be accessed at any point, and allows people to reach any other point in a matter of days.

\section{Access to the Global Mobility Infrastructure}

Although global mobility is highly desired, it leads to a dilemma for the global North. The expansion of human mobility carries the risk of making effective control of migration very difficult. If any world citizen can turn up at an airport in the global North within 48 hours after leaving her or his home, States in the global North risk losing control over the population present on their territory. This is all the more problematic as forcibly returning those who are unwilling to go back is a challenge. In this manner, something that is desired by the global North (increased human mobility) at the same time risks undermining sovereign control over its population and territory.

Faced with this dilemma, the countries in the global North have decided to have the best of both worlds. Instead of controlling access to their territory, they have sought to control access to the global mobility infrastructure-regardless of territory. A major way in which they do this is by effectively forcing airlines to control access to planes. Through carrier sanctions, states ensure that people who do not have the required documents-visas, in particularfor their country of destination will be refused embarkation. ${ }^{8}$ While this is relatively well known, there is less academic attention for security-related control of access to the global mobility infrastructure of people who do not need a visa. The US Electronic System for Travel Authorization (ESTA) and EU European Travel Information and Authorisation System (ETIAS) systems apply to travellers who are not nationals of the USA or an EU Member State respectively, and do not need visas. Nonetheless, they are required to obtain authorisation to travel to the US or the EU prior to their departure. Such authorisation is denied if travellers have been registered in particular information systems, or are on specific lists of persons to be excluded (Regulation (EU) 2018/1240). ${ }^{9}$ The US Secure Flight program goes even further because it applies

8 T. Rodenhäuser, 'Another Brick in the Wall: Carrier Sanctions and the Privatization of Immigration Control', 26 International Journal of Refugee Law 2014, p. 223-247; S. Scholten, The Privatisation of Immigration Control through Carrier Sanctions: The Role of Private Transport Companies in Dutch and British Immigration Control (Leiden: Koninklijke Brill NV, 2015).

9 R. Zaiotti, R. (2012): 'Practising homeland security across the Atlantic: practical learning and policy convergence in Europe and North America', 21 European Security 2012, p. 328-346; A. Alegre, I. Jeandesboz \& N. Vavoula, European Travel Information and Autorisation System (ETIAS): Border management, fundamental rights and data protection (Brussels: European Parliament, 2017). 
regardless of nationality - it may be used to deny even US citizens embarkation on domestic flights. Airlines have to submit passenger data for all US and foreign flights into, out of, and within the US, as well as for all flights operated by US based airlines between points outside the US, and for flights flying over the continental Unites States (including Alaska and Hawaii). If people are on the No Fly List, they are to be refused boarding. ${ }^{10}$ The criteria for being placed in the American No Fly List are secret. As a general rule this occurs because of a connection to terrorist activity. ${ }^{11}$ How such a connection is established is not clear-for example Adam Habib, the current Vice-Chancellor of Wits University in Johannesburg, South Africa, has been on the US No Fly List for years before being taken off; both why he was on the list, and why he was taken off is unclear. ${ }^{12}$

The denial of access to the global mobility infrastructure based on visa requirements, travel authorisation systems for visa-free nationalities, and no fly lists is by its nature selective. Selection through visa is based primarily on nationality. Citizens from certain countries do not need a visa to get on a plane to a country in the global North, while others do. Citizens of countries who need a visa may apply for one. The granting of visas is closely related to class, because (to take the EU as an example) article 21(1) of the Schengen Visa Code ${ }^{13}$ stipulates that one of the major criteria for granting or refusing a visa is whether the applicant presents a risk of illegal immigration (...) and whether the applicant intends to leave the territory of the Member States before the expiry of the visa applied for.' Possession of sufficient means of subsistence plays an important role (Article 21(3)(b) and Article 21(5) Schengen Visa Code). The EU Visa Handbook explicitly refers to applicants' socio-economic position in this context. It mentions as relevant factors inter alia the applicant's employment situation, regularity of income, the level of income, the applicant's social status in the country of residence '(e.g. elected to public office, NGO representative; profession with a high social status: lawyer, medical doctor, university professor)', as well as the possession of a house/real estate. ${ }^{14}$ Via this selection based

10 D. Lowe, The Flap with No Fly: Does the No Fly List Violate Privacy and Due Process Constitutional Protections?, 92 University of Detroit Mercy Law Review 2015, p. 157-190; see for a similar program in China, B. Pedroletti, En Chine, le fichage high-tech des citoyens, Le Monde 11 April 2018.

11 Lowe, supra note 10, at p. 160.

12 Adam Habib, opening statement during the Southern Perspectives on Migration conference, Wits University, Johannesburg, 5 September 2018.

13 Regulation 810/2009.

14 European Commission, Handbook for the processing of visa applications and the modification of issued visas, Consolidated version 15 September 2011, Annex to Commission Implementing Decision C(2011) 5501 final of 4 August 2011, (Brussels: European Commission, 2011), p. 61-62. 
on class, selection is indirectly also related to gender and race (because of the lower socio-economic status of women globally, and the weak socio-economic position of, for example, black people in South Africa and the Maghreb).

The selection of access to the global mobility infrastructure based on nationality leads to a situation in which some nationalities can circulate across the globe with minimal obstacles (global South countries tend to not require visas from global North citizens, or to grant them provided a visa fee has been paid), while the great majority of global South citizens are unable to access the global North (they need visa and most of them will be denied one if they apply).

One can see the effects of this most clearly on maps. One visualisation is based on the global Passport Index. ${ }^{15}$ The map based on the index divides countries into those whose nationals can access more than 100 other countries without needing an entry visa (white), and those whose nationals can access less than 100 other countries without an entry visa (grey). Another visualisation is the map which the European Commission puts on its website, indicating which nationalities do not need visa for the EU (green), which nationalities need a visa for the EU (red) and which nationalities even need a transit visa (dark red). ${ }^{16}$

When we compare the two maps, we see that the citizens of Europe, North America and Australia/New Zealand can travel easily around the world. Roughly speaking, citizens of Africa, the Caribbean and Asia need visas (in particular when they travel to the global North; there are significant regional free movement blocs in the global South). ${ }^{17}$ Russia has an ambivalent position in that its citizens need a visa (red on the second map) for the EU while they need visas for less than 100 countries in the world (white in the first map). Latin America has an ambivalent position in that most nationalities do not need a visa for the EU and can access over 100 countries visa-free. However, citizens of other Latin-American countries do need visas for the EU and can access less than 100 countries visa-free. Asia is more solidly on the underprivileged side of the spectrum, with Japan, South Korea and Malaysia as the exceptions.

The travel authorisation systems ESTA and ETIAS are seemingly unrelated to migration, as they apply to people who do not need to have a visa. However, to use the ETIAS example, applications for a travel authorisation will be checked in inter alia the Schengen Information System (SIS), the Entry/Exit System (EES), the Visa Information System (VIS), and Eurodac - the four databases

\footnotetext{
15 https://www.passportindex.org/, last accessed 13 November 2017.

16 https://ec.europa.eu/home-affairs/what-we-do/policies/borders-and-visas/visa-policy_en.

17 M. Czaika, H. de Haas \& M. Villares-Varela, The Global Evolution of Travel Visa Regimes, IMI Working papers 134 (Oxford: Oxford University Press 2017).
} 


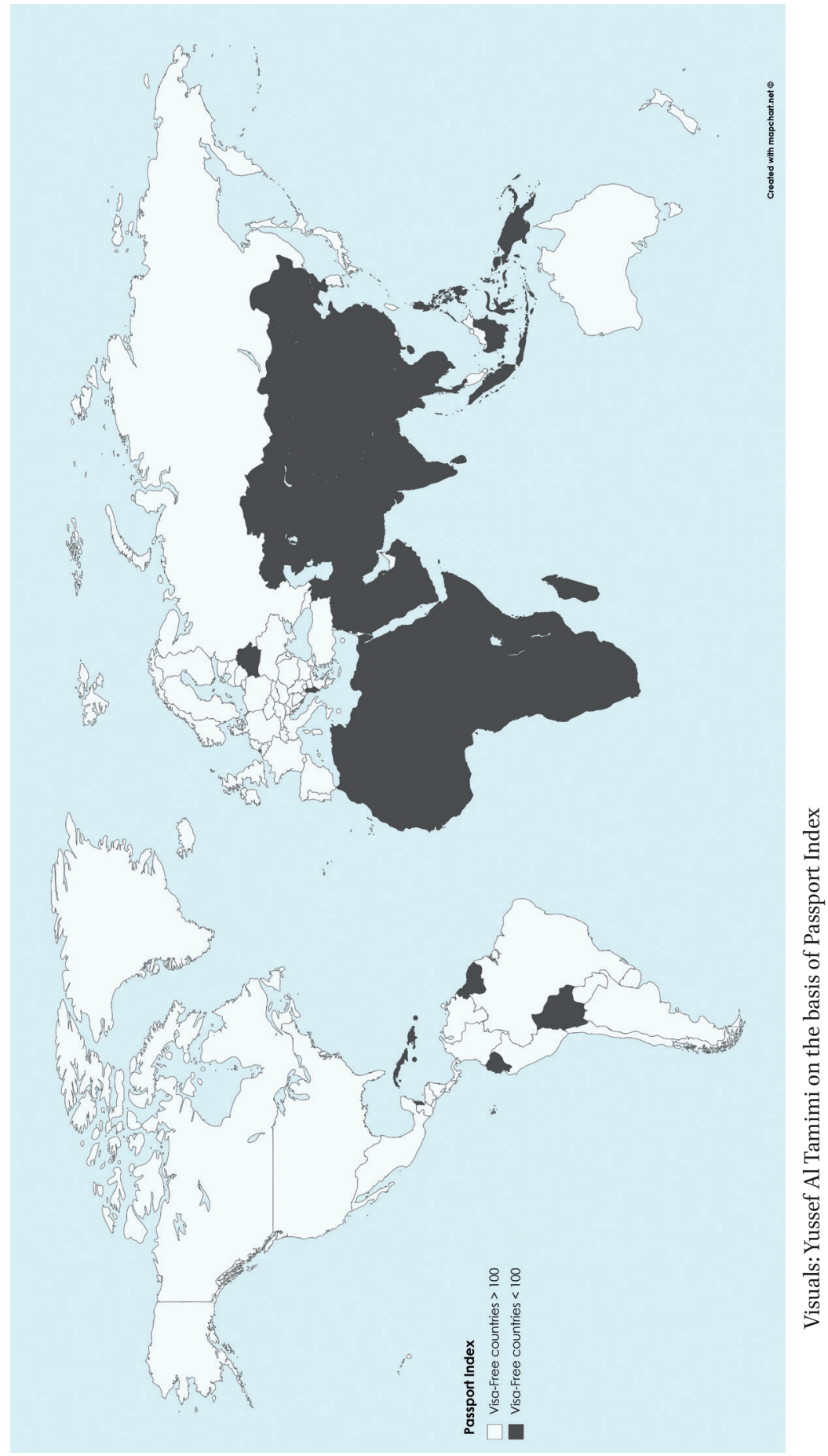




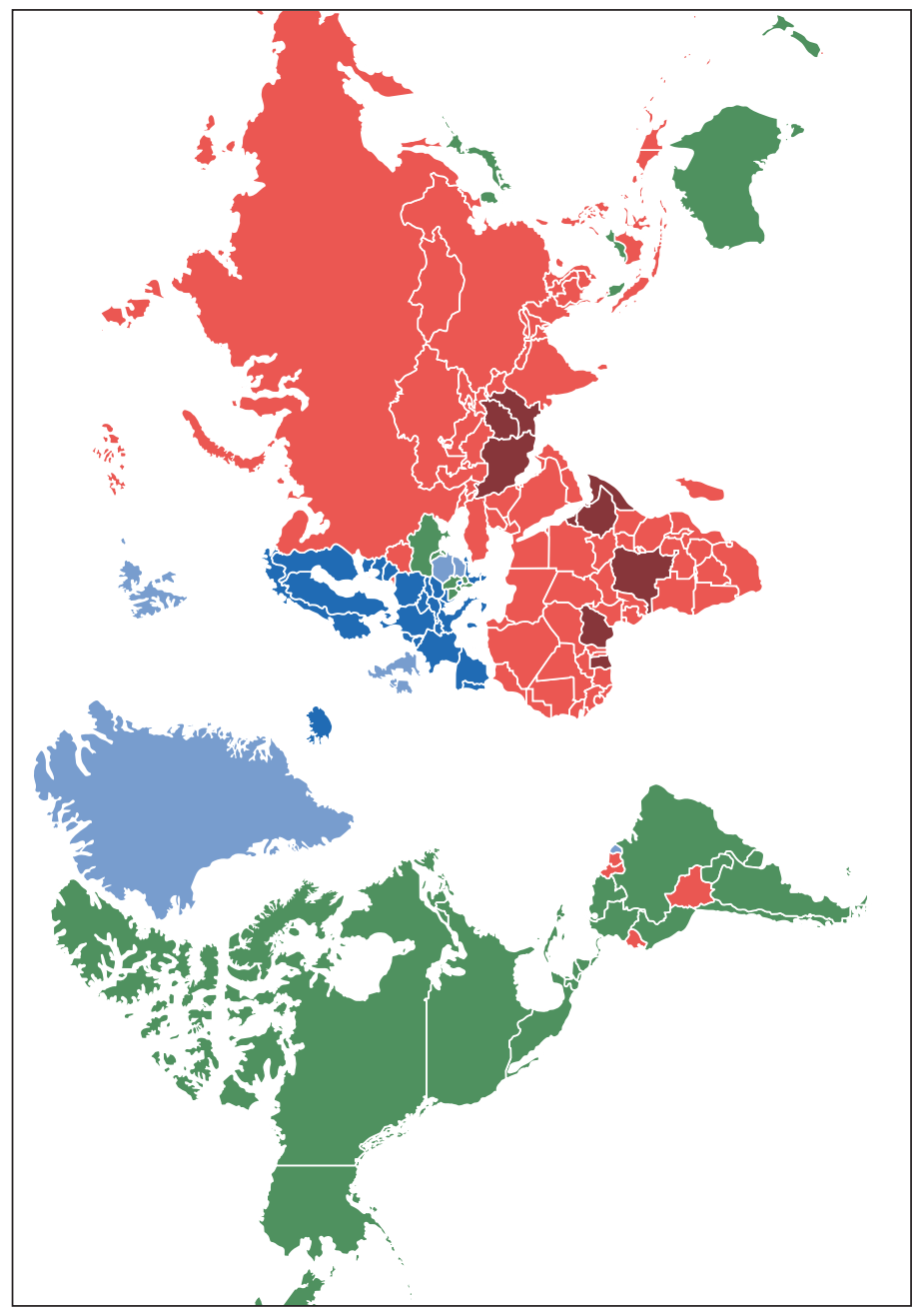

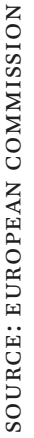


which are central to migration control in Europe. The other ETIAS checks concern criminality and security (Article 20(2) Regulation 2018/1240). In fact, ESTA and ETIAs function as a form of visa lite.

Controlling access to the global mobility infrastructure on the basis of nationality is an overwhelming success. In $2017,56.625$ people were refused entry at European airports during controls at the external borders, ${ }^{18}$ while the number of passengers arriving at European airports from outside the EU in that year was 189.718.026. ${ }^{19}$ This means that only three of each 10.000 passengers arriving at European airports from outside the EU arrive without the necessary documentation. Even if we allow for the possibility that people arrive with documents belonging to somebody else, and if we estimate that this happens as often as people being denied entry-then this still means that the enforcement of the control of access to the global mobility infrastructure is almost complete.

However, the almost complete control over access to the global mobility infrastructure has not led to a situation of complete control over the form of mobility subject to intense surveillance that is called migration. This is due to at least three phenomena.

The first phenomenon consists of circumventing the formal global mobility infrastructure. Denying access to the global mobility infrastructure has led to a shadow mobility infrastructure, in which human smuggling can flourish. The success of the control over access to the global mobility infrastructure has triggered the development of a parallel infrastructure, with its own physical structures (like hubs, pickup cars, boats), services (such as intermediaries, drivers) and law (i.a. the Palermo Protocols). If we take border deaths ${ }^{20}$ as a measure of the incidence of the reliance on this shadow mobility infrastructure, the conclusion would be that human smuggling has increased consistently with increased control over the access to the global mobility infrastructure. In other words: the increasing control over access to the global mobility infrastructure

18 Eurostat: Third country nationals refused entry at the external borders (migr-eirfs), (Luxembourg: Eurostat), https://ec.europa.eu/eurostat/data/database, last accessed 21 October 2018.

19 Eurostat, supra note 6.

20 T. Last et al., 'Deaths at the borders database: evidence of deceased migrants' bodies found along the southern external borders of the European Union', 43(5) Journal of Ethnic and Migration Studies 2017, p. 693-712. 
has been accompanied by increasing irregular migration. So the first limit to the success of control over access to the global mobility infrastructure is that people circumvent the official infrastructure altogether.

The second phenomenon that puts the success of migration control in perspective is legal entry followed by irregular presence. An important part of all irregular migrants discovered on the territories of European countries have entered the EU legally, but then overstay. Studies mention that this is the case for $70 \%$ of undocumented migrants in Italy; ${ }^{21}$ that it is 'typical' for Spain,;2 while it is also mentioned as important, but without indication of the frequency, for Greece, ${ }^{23}$ Germany, ${ }^{24}$ and the Netherlands. ${ }^{25}$ Overstaying is mentioned in general terms as an important 'source' of irregular presence on the territory. ${ }^{26}$ If overstaying is an important, and possibly the most important, source of irregular presence, that means that if the total number of persons legally entering the territory increases, the number of irregular migrants present on the territory will most likely also increase. Therefore, the numbers mentioned earlier on the increasing number of people flying to European airports from outside the EU may well imply that the number of overstayers has increased in a similar manner. A qualification of this hypothesis is that the increasing number of arrivals may be partly related to an increase of so-called hypermobility, i.e. an increasing number of people making frequent trips. Therefore, the increase in

21 F. Fasani, 'The Quest for la Dolce Vita? Undocumented Migration in Italy', in: A. Triandafyllidou (ed.), Irregular Migration in Europe. Myths and Realities (Farnham/ Burlington: Ashgate, 2010), p. 167-186, at p. 173 .

22 C. González-Enríques, C. (2010): 'Spain: Irregularity as a Rule', in: A. Triandafyllidou (ed.), Irregular Migration in Europe. Myths and Realities (Farnham/Burlington: Ashgate, 2010), p. $147-266$, at p. 256 .

23 T. Maroukis, 'Irregular Migration in Greece: Size and Features, Causes and Discourses', in: A. Triandafyllidou (ed.), Irregular Migration in Europe. Myths and Realities (Farnham/ Burlington: Ashgate, 2010), p. 93-114, at p. 103.

24 N. Cyrus \& V. Kovacheva, 'Undocumented Migration in Germany: Many Figures, Little Comprehension', in: A. Triandafyllidou, Irregular Migration in Europe. Myths and Realities (Farnham/Burlington: Ashgate, 2010), p. 125-144, at p. 134.

25 J. van der Leun \& M. Ilies, 'The Netherlands: Assessing the Irregular Population in a Restrictive Setting, in: A. Triandafyllidou, Irregular Migration in Europe. Myths and Realities (Farnham/Burlington: Ashgate, 2010), p. 187-206,at p. 198.

26 D. Vogel \& M. Jandl, 'Introduction into the methodological problem', in: A. Kraler \& D. Vogel (eds), Report on methodological issues 2008, p. 5-11, available at http://clandes tino.eliamep.gr/wp-content/uploads/2009/10/clandestino_report-on-methodological -issues_finalı2.pdf, last accessed 6 July 2017, p. 9-11; A. Triandafyllidou \& D. Vogel, 'Irregular Migration in the European Union: Evidence, Facts and Myths', in: A. Triandafyllidou, Irregular Migration in Europe. Myths and Realities (Farnham/Burlington: Ashgate, 2010), p. 291-299, at p. 294; comp. H. de Haas, 'The Myth of Invasion. The inconvenient realities of African migration to Europe', 29 Third World Quarterly 2008, p. 1305-1322, at p. 1309. 
overstaying may be lower than the total increase of arrivals. Another observation to be made is that overstayers are a more privileged group than people having recourse to smugglers. Overstayers apparently have or at least have had networks and resources allowing them to access the global mobility infrastructure. This access implies that they could travel safely, and possibly ${ }^{27}$ at lower cost, than people using irregular means to reach the global North.

Thirdly, an increasing number of empirical studies suggest that policy measures seeking to reduce immigration may actually increase the number of migrants on the territory of states in the global North. These studies show that migration restrictions under the current circumstances in the global North may not merely have limited success, but that they positively backfire. This occurs because restrictions interrupt seasonal and other forms of temporary or circular migration, and thereby promote more permanent settlement without effectively limiting the inflow of migrants. There are large scale case studies showing this effect on the US-Mexico border, ${ }^{28}$ on migration between Morocco and Spain, ${ }^{29}$ and on Caribbean migration. ${ }^{30}$ These case studies seem to be part of a general pattern to this effect. ${ }^{31}$

The proposed focus on the global mobility infrastructure therefore does not necessarily mean losing sight of restrictive migration policies, or of their partial failure to achieve their ends. Quite the contrary: it allows for a more comprehensive look at the way in which the regulation of access to the global mobility infrastructure results in a differentiation of human mobility, and in social stratification, along lines of nationality, race, class and gender.

\section{Discriminatory Access to the Global Mobility Infrastructure}

Reconceptualising externalisation of migration control as being about access to the global mobility infrastructure has two advantages over conceptualising

27 Not necessarily. The network that enables them to get a visa may come at a price.

28 D.S. Massey, 'A Missing Element in Migration Theories', 12 Migration Letters 2015, p. 279299; D.S. Massey, 'The Counterproductive Consequences of Border Enforcement', 37 Cato Journal 2017, p. 539-554.

29 H. de Haas \& T. Fokker, 'Intra-Household Conflicts in Migration Decision-Making: Return and Pendulum Migration in Morocco', 36 Population and Development Review 2013, p. 541-561.

30 M.-L. Flahaux \& S. Vezzoli, 'Examining the role of border closure and post-colonial ties in Caribbean migration', 6(2) Migration Studies 2017, p. 165-186, https://doi-org.vu-nl.idm .oclc.org/10.1093/migration/mnxo34.

31 H. de Haas et al., International Migration. Trends, determinants and policy effects, IMI working paper series no. 142 (Oxford: Oxford University Press, 2018). 
it merely as denying access, tightening borders, and non-entrée. It brings to light the intimate connection between the laws and policies promoting human mobility on the one hand, and the creation of a zone in the shadows of this very advanced form of transnational organisation on the other hand. Secondly, identifying this connection then allows for a new normative debate.

\subsection{The Zone Around the Global Mobility Infrastructure}

The global mobility infrastructure connects every point in the world with every other point in the world. As described above, access is strictly regulated. But in addition, the legal position of those denied entry is subject to particular forms of law. People who have been denied access to the global mobility infrastructure (for example through the denial of visa) are also denied the possibility to hold the excluding states accountable for the consequences of this exclusion. In addition, people who try to bypass their exclusion (for example, by using a smuggler to cross the desert or the sea) are subject to rather peculiar versions of international law while they are in the process of cross-border travel. And people who have succeeded in bypassing the system (including overstayers) are subject to equally peculiar versions of international law. In fact, the global mobility infrastructure is surrounded by a zone with a different form of legality compared to the legality within the global mobility infrastructure. This zone extends from points of entry (denial of visa) to points of exit (undocumented migrants present on the territory of states in the global North) and includes the global mobility bypasses (irregularised modes of travel). Seemingly disparate phenomena that have been addressed in existing literature on migration and international law can now be analysed as being part of a comprehensive process of creating an alternative form of legality for the excluded. The following is intended as a non-exhaustive enumeration of these alternative legalities.

European States exploit the gap between extensive notions of prescriptive and enforcement jurisdiction (allowing them to enforce their visa and migration policies outside their territories via carriers and third states) and limited notions of human rights jurisdiction which prevent them from being held accountable for the consequences. ${ }^{32}$ States actively cooperate to create and maintain a mobility infrastructure which is truly global. The global mobility infrastructure has come into existence through cooperation between states and private actors, through various platforms and fora, without an identifiable centre of control or coordination. This fuzzy organisation allows for dispersed application of visa and migration policies (hence the extensive prescriptive

32 Gammeltoft-Hansen 2011, supra note 1; Den Heijer 2011, supra note 1; Scholten 2015, supra note 8. 
and enforcement jurisdiction), but does not allow for confronting individual states with their individual responsibility (the infrastructure's fuzziness does not allow for identifying the single actor which could be responsible for a human rights violation).

Similarly, people who are subject to the externalisation of European migration law are not merely to be kept outside European territory, but also outside the material scope of European law. Judgments of the EU Court of Justice on the denial of humanitarian visas to a Christian family from Aleppo during the siege of that city, and on the EU-Turkey deal ensure that European law does not apply. ${ }^{33}$

The differentiated right to life for cross-border travellers means that the right to life of air passengers is protected through advanced legal and technical procedures, while the right to life of ferry passengers is well protected but not at such an advanced level. The protection of the right to life through international law of people who are allowed to use the global mobility infrastructure stands in stark contrast to the legal protection of the right to life of irregularised travellers, which takes the form of prohibiting and preventing their mobility. ${ }^{34}$

Search and rescue at sea, which is a traditional norm of international law, has been adapted and modified. European countries have created a Libyan Coast Guard, and are actively involved in running it. The preferred practice is that this nominally Libyan Coast Guard rescues people at sea and returns them to Libya. ${ }^{35}$ Together with the successful frustration of the activities of humanitarian NGOs in the Mediterranean, ${ }^{36}$ this leads to a situation where European states orchestrate returns which would be in violation of international law if it were done by European states themselves. ${ }^{37}$

People who have been denied access to the global mobility infrastructure, but who are nonetheless present on the territory of global North states are

33 T. Spijkerboer, 'Bifurcation of people, bifurcation of law: externalization of migration policy before the EU Court of Justice', 31 Journal of Refugee Studies 2018, p. 216-239. The appeal to the Court of Justice has been declared inadmissible because the appeal grounds were found to be 'incoherent', CJEU 12 September 2018, Cases C-208/17 P, C-209/17 P and $\mathrm{C}-210 / 17 \mathrm{P}, N F, N G$ and $N M v$ the European Council.

34 T. Spijkerboer, 'Wasted Lives. Borders and the Right to Life of People Crossing Them', 86 Nordic Journal of International Law 2017, p. 1-29.

35 N. Markard, 'The Right to Leave by Sea: Legal Limits on EU Migration Control by Third States', 27(3) European Journal of International Law 2016, p. 591-616.

36 I.a. M. Fink, K. Gombeer \& J. Rijpma, 'In search of a safe harbour for the Aquarius: The troubled waters of international and EU law', eumigrationlawblog.eu 9 juli 2018.

37 European Court of Human Rights (GC) 23 February 2012, Hirsi Jamaa et al. v Italy, application 27765/og. Also see contribution by Pijnenburg in this special issue. 
barred from entering into contractual relations (think of the obstacles for entering into contractual relations with airline and ferry companies; personal public transport cards in the country of irregular residence; the possibility to open a bank account, buy a house, enter into rental or employment contracts; receiving medical services; concluding a marriage). In addition, these people are not merely subjected to deportation detention (which has far less legal guarantees than criminal detention) and removal, but also to bullying practices of state authorities including dispersal policies, destruction of shelters, and the wilful destruction by state agents of tarpaulins and sleeping bags of migrants sleeping rough. ${ }^{38}$ All of these activities would be patently contrary to international law if they would be committed against nationals or regularly residing migrants. The denial of socio-economic rights of irregularly residing migrants and the limited guarantees surrounding their right to liberty (with the resulting vulnerability to abuse by public and private actors) are considered to be in conformity with human rights law. ${ }^{39}$

What connects these phenomena (the list is, once again, not intended to be exhaustive) is not only that people are kept physically away from the territories of the global North, and not merely that their access to the law of the global North is obstructed. The analyses mentioned in the introduction of this article, emphasising denial of access and policies of non-entrée, can easily obscure the bigger organisational structure of which these phenomena form parts, as well as their intrinsic relation to the promotion of forms of migration that are considered desirable ('mobility'). The substantive law of the global North itself is construed in such a manner that it incorporates, embodies, and represents the distinction between people who are encouraged to use the global mobility infrastructure on the one hand, and the people who are denied access to the global mobility infrastructure on the other hand. Access to the global mobility infrastructure comes with full-fledged international law, in the form of privileged protection of the right to life, to freedom, to family life, to health, to housing, to work. Denial of access comes with a denial of justice. Those denied access to the global mobility infrastructure are not subject to the same form of international law as those who have access to it. The law of the global North is not merely applied in a discriminatory manner. It is itself substantively excluding and exclusive. There is law for those who enjoy access to the global mobility infrastructure; and there is an altogether different kind of law for those who

38 M. Baumard, Au petit matin à Calais, les biens des migrants détruits, Le Monde 6 December 2017, p. 15 .

39 L. Slingenberg, The Reception of Asylum Seekers under International Law. Between Sovereignty and Equality (Oxford: Hart Publishing, 2014). 
are denied access. This partisan character of international law is obscured by technical pieces of doctrine on jurisdiction, state responsibility, the applicability of European law, transnational law, and the successful capture by states in the global North of elements of the governance of private actors and of states in the global South. The concept of the global mobility infrastructure is intended as an analytical tool to bring international law's partisan character to light so that it can become the subject of debate.

\subsection{New Normative Debates}

As an example of such a debate, one can begin to look at the discriminatory denial of access based on nationality and race. Migration law is a form of discrimination based on nationality. If one takes the definition of racial discrimination in Article 1(1) of the Convention on the Elimination of all forms of Racial Discrimination (CERD) at face value, migration law is also a form of racial discrimination because it involves a 'distinction, exclusion, restriction or preference based on race, colour, descent, or national or ethnic origin which has the purpose or effect of nullifying or impairing the recognition, enjoyment or exercise, on an equal footing, of human rights and fundamental freedoms in the political, economic, social, cultural or any other field of public life'. If migration law is not considered as a form of racial discrimination in international law, this is exclusively because Article 1(2) CERD provides that 'distinctions, exclusions, restrictions or preferences made by a State Party to this Convention between citizens and non-citizens' are not covered by the definition of the first paragraph. However, this acceptance of distinctions between citizens and non-citizens does not equal accepting discrimination 'against any particular nationality' (Article 1(3) CERD, on nationality law), a concept which arguably encompasses not just discrimination against people with one particular nationality, but also against a group of particular nationalities. As has been shown before, it is impossible to deny that the global mobility regime thas the (...) effect of nullifying or impairing the (...) enjoyment or exercise, on an equal footing, of human rights and fundamental freedoms in the political, economic, social, cultural or any other field of public life' (Article 1 CERD). International law, which is one of the three constituent elements of the global mobility infrastructure (as discussed in section 3 above), in its present form denies particular nationalities such enjoyment or exercise. Such a distinction would be acceptable if it would target non-citizens (Article 1(2) CERD), but arguably it is a violation of Article 1 CERD to nullify or impair the enjoyment of the right to life, to be free from torture, to family life, to health care, to work and housing for some non-citizens, but not for others, based on their nationality. 
Nonetheless, discrimination based on citizenship has been accepted in migration law in the past 130 years. ${ }^{40}$ However, the areas of human activity that are covered by the discrimination which is at the heart of migration law have been drastically expanded over the past few decades. States of the global North have introduced laws and policies requiring residence permits and visa for activities as varied as concluding contracts or going to the doctor. As a consequence, the acceptance of racial discrimination inherent in contemporary migration law has spread out to fields that are not about cross-border travel in the strict sense of the word, but about other human activities. This extensive diffusion of discrimination is supposed to legitimise a social structure as a result of which thousands of people of particular nationalities die annually at the borders of the global North; to legitimise the destruction of improvised dwellings of those who have nonetheless succeeded in making it to wealthy countries; to legitimise criminalising entering into a labour or rent agreement or a marriage; and to legitimise exclusion from medical care. In essence, discrimination based on nationality which is covered by the concept of racial discrimination in CERD is legitimised by labelling such discrimination as related to migration policy. Even if one fully acknowledges the right of each State 'to control the entry of non-nationals into its territory', ${ }^{41}$ the question whether this implies the right of States to redefine any issue as an issue of migration control that is covered by the exception of Article 1(2) CERD is to be questioned. A traditional international law approach would suggest that Article 1(2), as an exception to the general rule of Article 1(1), is to be interpreted narrowly.

A second normative debate that can be addressed through the notion of the global mobility infrastructure is the discrimination based on class and indirectly on gender that is inherent in the infrastructure. The discrimination based on nationality is related to wealth at the national level-citizens of rich countries are exempt from entry visa requirements if they want to go to other countries in the global North, while citizens of poor countries are not. But more directly, citizens of countries for which a visa is required are distinguished along lines of class. As outlined above (supra para. 4), one of the conditions for granting a visa is that the applicant has a stable and secure socio-economic position in the country of nationality. Because of the globally disadvantaged socio-economic position of women, the excluding effects of

40 United States Supreme Court in Chae Chan Ping v US (aka the Chinese Exclusion Case), 130 U.S. 581 (1889); European Court of Human Rights 28 mei 1985, Abdulaziz, Cabales and Balkandaliv United Kingdom, 9214/80; 9473/81; 9474/81.

41 European Court of Human Rights, Abdulaziz, Cabalaes and Balkandaliv United Kingdom, supra note 40 , para. 67 . 
this requirement are more intrusive for women than for men. Discrimination on the basis of class is considered unproblematic in international law, presumably because wealth (or poverty) is considered to be a matter of personal merit in a capitalist system. But the indirect gender discrimination of the visa system can be discussed in light of the prohibition of gender discrimination both in general international law (e.g. Article 26 of the International Covenant on Civil and Political Rights) as well as in the Convention on the Elimination of all forms of Discrimination against Women, CEDAW. Interestingly, religion seems not to be a legitimate ground for discriminatory access. ${ }^{42}$

As a consequence of the forms of discrimination outlined above, the global mobility infrastructure is populated by a disproportionally white, disproportionally wealthy, and disproportionally male population. The privileged class does not only enjoy good, quick and safe transport across the globe; it also can to rely on advanced forms of international law. The zone surrounding the global mobility infrastructure on all sides is populated disproportionally by a non-white, poor and female population. The excluded do not have access to quick and safe transport, and ironically their cross-border travel will usually be more expensive. This excluded population cannot rely on meaningful versions of international law. Its marginalisation is not ground for protection by fullfledged international law. International law does not redress, but to the contrary reflects and reinforces their exclusion. Their lives are dispensable, their health is merely of interest if diseases are contagious, and if State agents destroy their shelters and pierce their blankets, that is construed as a legitimate consequence of the behaviour of the victims.

The least one can observe about this, is that the situation where people are excluded from access to the global mobility infrastructure on the basis of nationality, race, class and gender is not a natural situation. It is a system that has been developed since the end of the Cold War. Its efficacy is subject to serious debate. But normative debates are about more than efficacy alone. The notion of the global mobility infrastructure enables a reflection of the legitimacy of a legal system in which discrimination on the basis of nationality, race, class and gender plays a central role. It is time to question the ways in which international law is made to embody discrimination, instead of (in the terminology of CERD and CEDAW) 'eliminating' it.

42 See on the US travel ban, United States Supreme Court 28 June 2018, in Trump v Hawaii, 585 US (2018), at p. 34 . 